Volume 5 No 1 September 2019

p-ISSN : $2460-8750$ e-ISSN : $2615-1731$

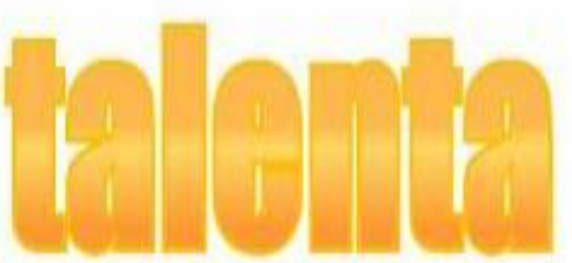

DOI: https://doi.org/10.26858/talenta.v5i1.9773

\title{
STRUKTUR PERANTI MENTAL (ID, EGO, SUPER EGO) PESANTREN DALAM INTIMASI DENGAN LAWAN JENIS
}

\author{
Herlambang Andi Prasetyo Aji \\ Psikologi Pendidikan Islam, UIN Sunan Kalijaga \\ herlambangandi29@gmail.com
}

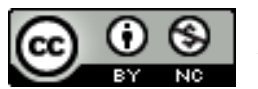

C2019 -JPT Fakultas Psikologi Universitas Negeri Makassar. Ini adalah artikel dengan akses terbuka di bawah licenci CC BY-NC-4.0 (https://creativecommons.org/licenses/by-nc/4.0/ ).

\begin{abstract}
Adolescence is a period where there is a strong relationship to the opposite sex and this term is often referred to as an intimacy relationship. Intimation in the structure of mental devices is a necessity that demands to be fulfilled. Adulthood students who are in the boarding school environment in particular indirectly have to maintain their good name in the eyes of civil society as boarding school graduates especially in their relations to the opposite sex. Intimate needs are the natural instincts of adolescents but on the other hand these needs will also be fatal if those who graduate from the boarding school university are wrong in implementing them. For this reason, the researchers want to explore the dynamics of mental devices in the context of intimacy relationships, especially in Islamic boarding schoolbased university students. The researcher used qualitative research with a phenomenological approach. The researcher used a purposive sampling technique in determining the research subject. The method of data collection in this study used observation and in-depth interviews with four subjects. In general, the process experienced by most research subjects in overcoming the impulse that they feel, namely by using the ego self defense mechanism in the form of compensation, a mechanism that someone prefers to pursue a goal, with a more active effort in trying to overcome the lack which are actually. In short, they prefer to strengthen themselves.
\end{abstract}

KeyWords: Id; ego; super ego; intimacy; boarding school

ABSTRAK: Masa remaja adalah masa dimana ada relasi yang kuat terhadap lawan jenis istilah ini sering disebut sebagai hubungan intimasi. Intimasi di dalam struktur peranti mental merupakan suatu kebutuhan yang menuntut untuk dipenuhi. Masa dewasa mahasiswa dan mahasiswi yang berada di lingkungan pesantren khususnya secara tidak langsung harus menjaga nama baik mereka di mata civil society sebagai lulusan pesantren terutama di dalam hubungan mereka terhadap lawan jenis. Kebutuhan intim merupakan naluri alamiah remaja namun disisi lain kebutuhan tersebut juga akan berakibat fatal apabila mereka yang dari lulusan universitas pesantren salah dalam mengimplementasikannya. Atas dasari ini peneliti ingin lebih mendalami dinamika struktur peranti mental dalam konteks hubungan intimasi terutama pada mahasiswa-mahasiswi universitas berbasis pesantren. Peneliti menggunakan penelitian kualitatif dengan pendekatan fenomenologis. Peneliti menggunakan teknik purposive sampling dalam menentukan subjek penelitian. Metode pengumpulan data dalam penelitian ini menggunakan observasi dan wawancara mendalam dengan empat subjek. Secara umum proses yang dialami sebagian besar subjek penelitian dalam mengatasi dorongan yang dirasakannya, yaitu dengan cara ego menggunakan mekanisme pertahanan diri dalam bentuk kompensasi, sebuah mekanisme bahwa seseorang lebih memilih mengejar suatu tujuan, dengan usaha yang lebih giat ke dalam usahanya itu untuk mengatasi rasa kekurangan yang sebenarnya. Singkat kata mereka lebih memilih untuk memantaskan diri mereka. 
Kata kunci: Id; Ego; Super ego; intimasi; pesantren

\section{Pendahuluan}

Intimasi adalah sebuah kemampuan untuk dekat dengan orang lain, seperti sebagai kekasih, teman atau anggota masyarakat, Erikson (dalam boeree, 2005). Disamping itu, kemampuan-kemampuan untuk berkomunikasi seseorang juga berperan penting di dalam menjalin dan meningkatkan hubungan intimasi di dalam menjalan hubungan romantis. Ada istilah yang mengemukakan bahwa sebuah intimasi dan komunikasi adalah saling berkaitan dan pasangan yang mengalami kesulitan dalam komunikasi dikatakan tidak mempunyai intimasi di dalam hubungan merek (septian, 2017). Erikson (dalam Septian, septian 2017) mengatakan bahwasanya selama masa dewasa muda, seseorang akan dianggap matang apabila dirinya sukses mengatasi krisis yang dikenal dengan istilah sebutan intimacy versus isolation (keintiman versus pengasingan). Erikson juga menekankan bahwasannya sebuah individu-individu dimotivasi untuk meleburkan diri dengan orang lain, sehingga membentuk keintiman. Hal ini berasal dari kemampuan untuk mencintai seseorang.

Dikatakan bahwa sebuah tugas perkembangan pada masa dewasa muda adalah menjalin hubungan intim dengan lawan jenis (Papalia dkk, 2004), termasuk dalam memilih jodoh, belajar hidup dengan suami atau istri, mulai membentuk keluarga, mengasuh anak, mengemudikan rumah tangga, menemukan kelompok sosial, menerima tanggung jawab warga negara, dan mulai bekerja (Monks dkk, 1996). Proses-proses dalam manjalani hubungan intimasi juga dapat diperoleh dari proses hubungan pacaran.

Pacaran menurut Santrock (dalam Dariyo, 2004) merupakan suatu masa pendekatan antar individu dengan individu yang lainnya yang ditandai dengan saling pengenalan pribadi antara satu dengan yang lainnya baik mengungkapkan kelebihan maupun kekurangan dari masing-masing individu. Pada tahapan ini pacaran juga diasumsikan sebagai masa persiapan seseorang untuk dapat menuju ke jenjang pertunangan dan pernikahan yang lebih serius di dalam kehidupan.

Di dalam Yudistriana dkk. (2010) Pacaran pada hakikatnya adalah sebagai proses mengenal, memahami lawan jenis, dan belajar membina hubungan dengan berkomunikasi unntuk menyelesaikan konflik yang terjadi di dalamnya karena di dalam sebuah hubungan pasti tidak lepas dari yang namanya sebuah konfilk. Karena di dalam sebuah hubungan khususnya dalam pacaran ada yang disebut tahap keintiman. Pada tahap ini merupakan kesempatan bagi seseorang untuk mengungkapkan diri dengan pasangan secara lebih dekat. Kendati demikian, proses hubungan intimasi terhadap lawan jenis ini atau pacaran menjadi hal yang selalu di waspadai dalam implementasinya di dalam sebuah kehidupan terlebih lagi di kalangan civil society khususnya bagi dewasa muda yang sedang duduk dibangku universitas yang berbasis pesantren.

Masa dewasa apalagi mereka yang merupakan lulusan pesantren sangat memegang teguh ajaran islam dalam penerapannya di dalam masyarakat. Apalagi ketika latar belakang mereka yang lulusan pesantren telah diketahui oleh kaum civil society mereka dituntut untuk lebih menjaga sikap dan perilaku mereka di dalam kehidupan sehari-hari, termasuk di dalam hal pergaulan antara kaum laki-laki dan perempuan yang biasa disebut dengan pacaran. Hubungan Intimasi merupakan merupakan suatu kebutuhan, di dalam Murray (dalam Hall, 1993) semua yang termasuk suatu kebutuhan pada dasarnya 
adalah menuntut suatu pemenuhan. Ketika kebutuhan tersebut sudah dipenuhi maka individu akan terpuaskan. Oleh Freud (dalam Alwisol, 2010) menerangkan bahwa suatu kebutuhan letaknya berada di dalam id. Id adalah sistem kepribadian yang asli, berisi semua aspek psikologis yang diturunkan, seperti insting, impuls, dan dorongandorongan psikologis. Di dalam psikologi analisis ada struktur peranti mental yang terdiri dari Id, Ego, dan Super Ego. Id di dalam struktur peranti mental ada superego yang berisi hati nurani yang bekerja berdasarkan prinsip idealistik, dan ego merupakan penentu perilaku yang bekerja berdasarkan prinsip realistik. Semua struktur peranti mental tersebut saling berinteraksi dalam pemenuhan kebutuhan id.

Setiap orang ketika sudah menginjak masa remaja ke dewasa muda tentu saja akan mengalami hal yang disebut intimasi. Karena intimasi merupakan naluri alamiah manusia ketika rentan umur telah menginjak masa dewasa muda. Sebuah kebutuhan struktur peranti mental terutama id untuk dipenuhi terkadang tidak sejalan dengan superego mahasiswa-mahasiswi universitas berbasis pesantren. Di dalam ajaran agama terutama agama Islam pacaran sangat dilarang keras bahkan mereka menganggap pacaran adalah perbuatan yang termasuk kedalam dosa besar di dalam agama Islam. Freud (dalam Alwisol, 2010) menyebutkan bahwasannya sebuah kecemasan merupakan fungsi ego untuk memperingatkan individu tentang kemungkinan datangnya ancamanancaman sehingga dapat disiapkan reaksi yang adaptif untuk mencegah hal-hal yang tidak diinginkan. Struktur peranti yang dinamakan Ego memiliki suatu mekanisme pertahanan yang disebut mekanisme pertahanan diri (defence mechanism) yang digunakan untuk mengurangi suatu tegangan atau dorongan-dorongan berupa kebutuhan.

Ada sebuah definisi bahwa masa dewasa muda merupakan permulaan dari tahap baru dalam kehidupan seseorang. Periode ini merupakan tanda bahwa telah tiba saat bagi seseorang untuk dapat mengambil bagian dalam tujuan hidup yang telah dipilih dan menemukan kedudukan dirinya dalam kehidupan (Turner \& Helms, 1995). Ada beberapa tantangan dalam mencapai tujuan dan menemukan kedudukan dirinya dalam kehidupan adalah merealisasikan tugas perkembangan usia dewasa muda. Beberapa tugas-tugas dalam perkembangan pada dewasa muda adalah menjalin hubungan intim terhadap lawan jenis, (Papalia dkk, 2004), memilih jodoh, belajar hidup dengan suami atau istri, mulai membentuk keluarga, mengasuh anak, mengemudikan rumah tangga, menemukan kelompok sosial, menerima tanggung jawab warga negara, dan mulai bekerja (Monks dkk, 1996).

Menurut Hurlock (2004) periode yang dinamakan masa dewasa dimulai pada rentang usia 18 tahun sampai kira-kira 40 tahun, disaat perubahan-perubahan fisik dan perubahan psikologis yang menyertai berkurangnya kemampuan reproduktif. Seluruh keputusan-keputusan yang dibuat pada rentang usia ini kebanyakan berkaitan dengan suatu hubungan intimacy (Papalia dkk, 2004). Terutama pada masa dewasa muda yang salah satu tugas perkembangannya adalah menjalin hubungan intim, dan membentuk keluarga di dalam berkehidupan jangka panjang.

Pada saat seseorang mulai memasuki masa yang dinamakan masa dewasa muda, masa itu identik dengan menjalin relasi yang dekat dengan lawan jenis yang disebut dengan hubungan intimasi. Erikson (dalam Turner dkk, 1995) mengatakan bahwa selama masa dewasa muda, seseorang akan dianggap matang apabila dirinya sukses mengatasi krisis yang dikenal dengan nama intimacy versus isolation (keintiman versus pengasingan). Sekali lagi Erikson menekankan bahwa individu dimotivasi 
untuk dapat meleburkan diri dengan orang lain secara tidak langsung, sehingga membentuk keintiman. Pernyataanpernyataan semacam ini berasal dari kemampuan untuk mencintai seseorang. Sebuah hubungan intim dapat terbentuk atas rasa saling percaya dan cinta yang diperoleh dari attachment pada masa bayi, dan dari hal ini individu dewasa muda mengembangkan perasaan saling tergantung. Sekali lagi Erikson memandang nahwa perkembangan hubungan yang intim dapat dikatakan sebagai tugas krusial bagi seorang dewasa muda. Sebuah hubungan yang dinamakan intimasi dapat mencakup kontak seksual atau tidak.

Masa yang dinamakan dewasa muda adalah masa permulaan dimana seseorang mulai menjalin suatu hubungan yang serius dengan lawan jenisnya. Pada masa ini mulai muncul keinginan untuk lebih dekat dan akrab dengan lawan jenis terhadap suatu kebutuhan akan intimasi. Menurut Murray (dalam Hall, 1993) semua yang dinamakan kebutuhan pada dasarnya menuntut untuk dipenuhi. Apabila setiap kebutuhan dipenuhi oleh ego maka seorang individu akan merasa sangat puas. Istilah kebutuhan menurut Freud (dalam Alwisol, 2010) terletak di dalam struktur peranti mental yang dinamakan Id. Id merupakan induk dari sistem kepribadian atau struktur peranti mental dan dibawa sejak lahir. Kendati demikian, kebutuhan yang tidak terpenuhi oleh ego maka muncul kecemasan sebagai dampak dari konflik yang menjadi bagian kehidupan yang tak terhindarkan. (Alwisol, 2010).

Freud (dalam Alwisol, 2010) mengungkapkan bahwasannya di dalam struktur peranti mental, id tidak bekerja sendiri. terdapat struktur peranti mental ego yang bekerja berdasarkan prinsip realistik (realistic principle) dan superego yang bekerja berdasarkan prinsip idealistik yang berupa moral-moral (idealistic principle). Freud mengungkapkan superego merupakan sebuah kekuatan moral dan etik dari kepribadian seseorang, yang mana struktur ini beroperasi memakai prinsip idealistik (idealistic principle) sebagai lawan dari prinsip kepuasan id dan prinsip realistik ego. Disamping itu ego disebut juga sebagai eksekutor kepribadian, karena ego yang mengontrol pintu-pintu ke arah tindakantindakan dan memilih segi-segi lingkungan ke mana ia akan memberikan sebuah respon, lalu kemudian memutuskan insting-insting manakah yang akan dipuaskan dan bagaimana cara pelampiasan tersebut. Ketiga struktur peranti mental pasa setiap orang memiliki fungsinya sendiri.

Setiap kebutuhan Id untuk dipenuhi terkadang tidak sejalan dengan hati nurani seseorang dan hal itu menimbulkan sebuah konflik yang berupa sebuah kecemasan dan tegangan. Freud (dalam Alwisol, 2010) mengungkapkan bahwasannya definisi kecemasan merupakan fungsi ego untuk memperingatkan individu tentang kemungkinan datangnya sebuah gangguan sehingga dapat disiapkan reaksi yang adaptif dalam menghadapi gangguan tersebut. Kendati demikian, apabila datang beberapa tekanan kecemasan yang berlebih-lebihan dapat membuat ego terpaksa menempuh cara-cara ekstrem untuk menghilangkan tekanan yang muncul. Struktur peranti mental Ego memiliki suatu mekanisme pertahanan yang disebut mekanisme pertahanan diri (defence mechanism) yang digunakan untuk mengurangi tegangan atau dorongan-dorongan berupa kebutuhan.

\section{METODE}

Penelitian yang dilakukan ini menggunakan deskriptif kualitatif, yaitu merupakan penelitian yang berusaha untuk mengambarkan atau melukiskan objek yang akan diteliti berdasarkan fakta yang ada di lapangan. Hasil dari Penelitian nantinya yang datanya dikumpulkan berupa kata-kata, gambar dan bukan angka-angka. Tentang metode pengumpulan data yang digunakan 
yaitu, observasi, wawancara, dokumentasi. Kemudian teknik analisa data dalam penelitian ini, mengacu pada model interaktif yang menyebutkan terdapat empat prosedur dalam analisis data kualitatif, pengumpulan data, reduksi data, penyajian data dan kesimpulan.

\section{HASIL DAN PEMBAHASAN}

Peneliti melakukan wawancara kepda mahasiswa-mahasiswi universitas berbasis pesantren XX yang berada di PonorogoJawa Timur. Universitas berbasis pesantren ini merupakan salah satu universitas terbesar di Indonesia bahkan di Asia tenggara. a. Struktur peranti mental ID Universitas berbasis pesantren. Setelah dilakukan proses wawancara kepada subjek-subjek maka di peroleh hasil sebagai beriku dari segi ID

\section{NO SUBJEK}

1.

\section{ID}

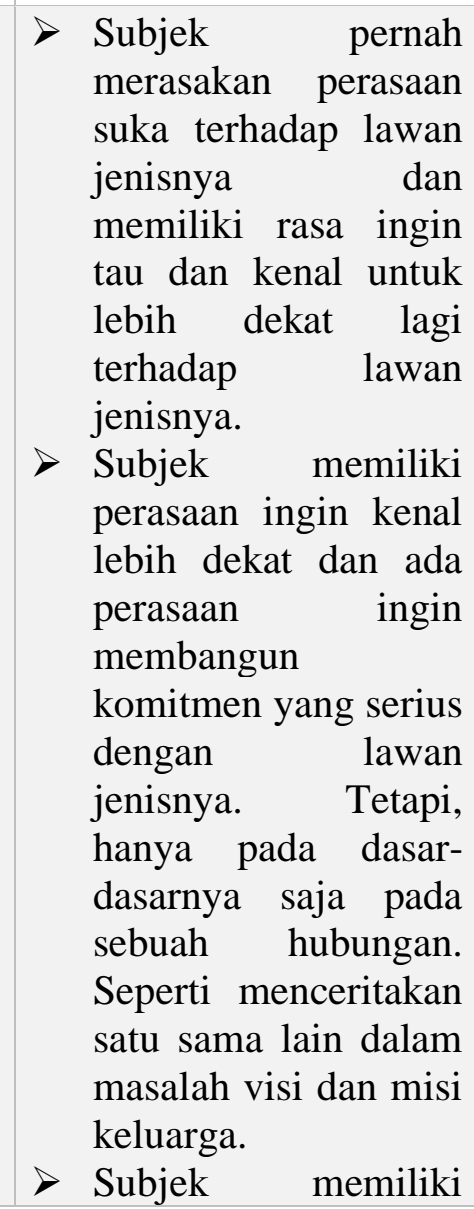

Tetapi, sebelum melakukan wawancara, peneliti meminta kesepakatan terhadap subjek-subjek mengenai waktu dan tempat yang disepakati untuk melakukan proses wawancara. Ketika melakukan proses wawancara, subjek menjawab semua pertanyaan yang diberikan oleh peneliti dengan baik dan tanpa adanya gangguan komunikasi dan intervensi dari pihak manapun. Kegiatan wawancara dilakukan langsung oleh peneliti kepada subjek sebanyak beberapa waktu. Berdasarkan hasil wawancara peneliti diperoleh data sebagai berikut:

\begin{tabular}{|c|c|c|}
\hline & & $\begin{array}{lr}\text { keinginan } & \text { yang } \\
\text { sangat besar } & \text { untuk } \\
\text { mengetahui } & \text { lebih } \\
\text { jauh } & \text { terhadap } \\
\text { kepribadian } & \text { lawan } \\
\text { jenisnya. } & \end{array}$ \\
\hline 2. & PN & $\begin{array}{l}\text { Subjek ada rasa } \\
\text { ketertarikan terhadap } \\
\text { lawan jenisnya sejak } \\
\text { umur } 6 \text { tahun. Atau } \\
\text { semenjak duduk di } \\
\text { bangku sekolah dasar. } \\
>\text { Subjek ada rasa ingin } \\
\text { menjadikan lawan } \\
\text { jenis sebagai lebih } \\
\text { dari sahabat. } \\
>\text { Subjek memiliki } \\
\text { keinginan untuk } \\
\text { selalu bersama sama } \\
\text { terhadap lawan } \\
\text { jenisnya. }\end{array}$ \\
\hline 3. & $\mathrm{AN}$ & $\begin{array}{lr}\text { Subject ada rasa } \\
\text { ketertarikan ketika } \\
\text { liburan keluar dari } \\
\text { pesantren. } \\
\text { perasaan terhadap } \\
\text { lawan jenis muncul } \\
\text { lagi ketika menginjak } \\
\text { di bangku kuliah } \\
\text { selepas lulus dari } \\
\text { pesantren. }\end{array}$ \\
\hline
\end{tabular}




\begin{tabular}{|c|c|c|}
\hline & & $\begin{array}{l}\text { Rasa ketertarikan } \\
\text { terhadap lawan jenis } \\
\text { itu muncul ketika } \\
\text { melihat di depan } \\
\text { mata. Subjek } \\
\text { mengakui bahwa di } \\
\text { dalam pondok jarang } \\
\text { melihat terhadap } \\
\text { lawan jenisnya. } \\
\text { Sehingga ketika } \\
\text { berada di luar pondok } \\
\text { perasaan itu muncul } \\
\text { secara menggebu- } \\
\text { gebu. Tetapi masih } \\
\text { dalam pengontrolan. } \\
\text { Subjek memiliki } \\
\text { perasaan untuk kenal } \\
\text { lebih dekat terhadap } \\
\text { lawan jenisnya dan } \\
\text { ingin menjalin } \\
\text { hubungan yang serius } \\
\text { untuk kedepannya. }\end{array}$ \\
\hline 4. & $\mathrm{AB}$ & $\begin{array}{lr} & \text { Subjek memiliki } \\
\text { perasaan } & \text { suka } \\
\text { terhadap lawan } & \text { jenisnya sejak duduk } \\
\text { dibangku Sekolah } & \text { Menengah Pertama. } \\
& \text { Subjek memiliki rasa } \\
\text { untuk memiliki } & \text { terhadap lawan jenis. } \\
> & \text { Subjek memiliki rasa } \\
\text { penasaran terhadap } & \text { lawan jenisnya. Dan } \\
\text { ingin mencoba untuk } \\
\text { mendekati dan untuk } \\
\text { memahami perasaan } \\
\text { lawan jenisnya }\end{array}$ \\
\hline 5. & $\mathrm{ZN}$ & $\begin{array}{lr}\text { Subjek } & \text { memiliki } \\
\text { keinginan } & \text { untuk } \\
\text { bermesraan } & \text { terhadap } \\
\text { lawan } & \text { jenisnya } \\
\text { alasannya } & \text { perasaan } \\
\text { yang muncul itu } \\
\text { wajar karena sudah } \\
\text { mengijak }\end{array}$ \\
\hline
\end{tabular}

\begin{tabular}{|l|l|}
\hline \multicolumn{1}{|c|}{ dewasa muda } \\
Subjek memiliki rasa \\
untuk ingin \\
mendengarkan \\
perasaan lawan \\
jenisnya \\
$>\begin{array}{l}\text { Subjek memiliki rasa } \\
\text { penasaran terhadap } \\
\text { hubungan terhadap } \\
\text { lawan jenisnya untuk } \\
\text { saling memahami } \\
\text { kepribadiannya } \\
\text { secara mendalam. }\end{array}$ \\
\hline
\end{tabular}

b. Struktur peranti mental Super Ego Universitas berbasis pesantren. Setelah dilakukan proses wawancara kepada subjek-subjek maka di peroleh hasil sebagai beriku dari segi Super Ego:

\section{NO SUBJEK SUPER EGO}

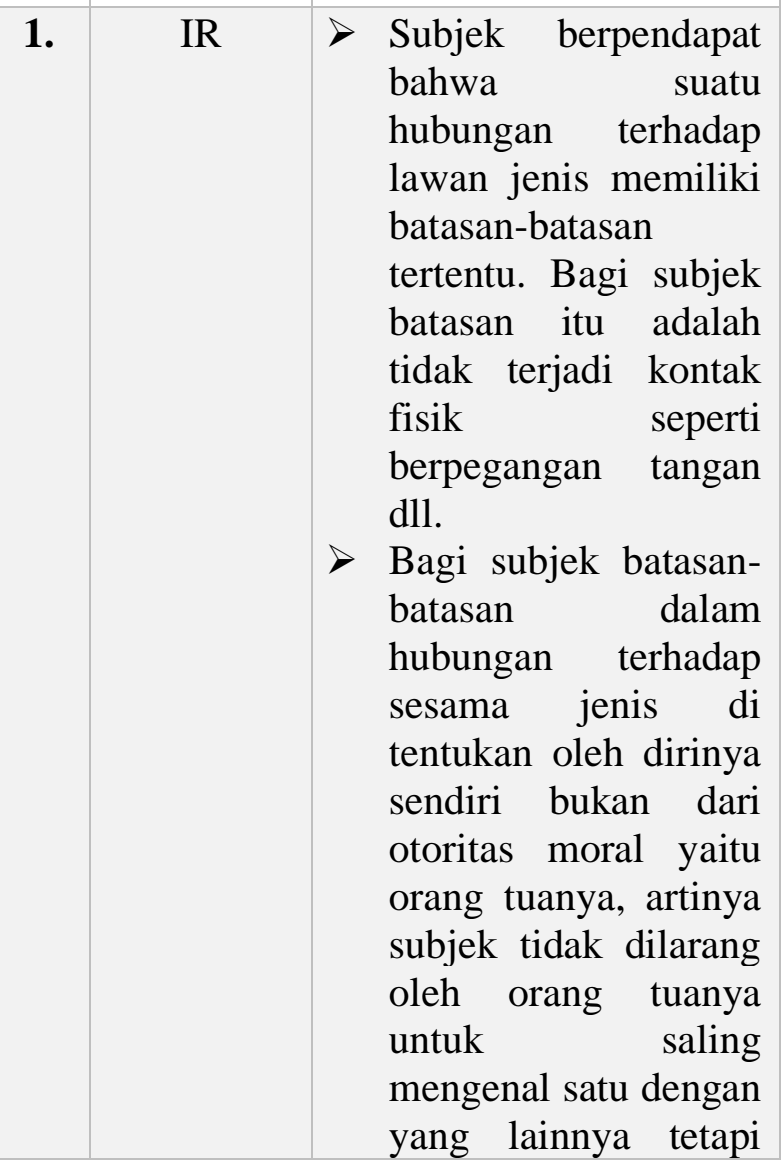




\begin{tabular}{|c|c|c|c|}
\hline & & & $\begin{array}{l}\text { harus tau batasan dan } \\
\text { batasan itu di } \\
\text { serahkan kepada } \\
\text { subjek sendiri. }\end{array}$ \\
\hline 2. & PN & & $\begin{array}{l}\text { Subjek berpendapat } \\
\text { bahwa tidak setuju } \\
\text { dengan istilah } \\
\text { pacaran. Karena itu } \\
\text { akan merusak harga } \\
\text { diri seorang lulusan } \\
\text { pesantren dimata } \\
\text { masyarakat. } \\
\text { Subjek mengaku telah } \\
\text { didik orang tuanya } \\
\text { sejak kecil dan } \\
\text { dilarang keras apabila } \\
\text { melakukan hubungan } \\
\text { terhadap lawan jenis } \\
\text { walaupun hanya } \\
\text { sebatas rasa ingin tau } \\
\text { satu dengan yang } \\
\text { lainnya. }\end{array}$ \\
\hline 3. & AN & & 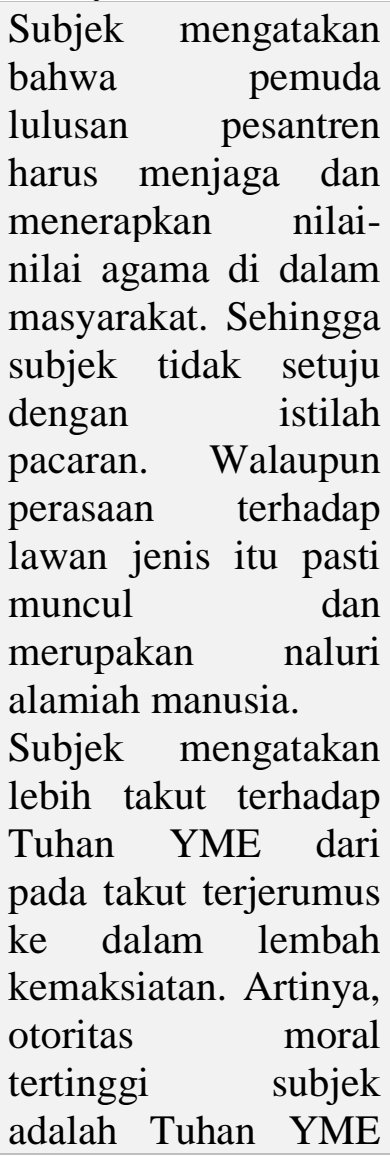 \\
\hline
\end{tabular}

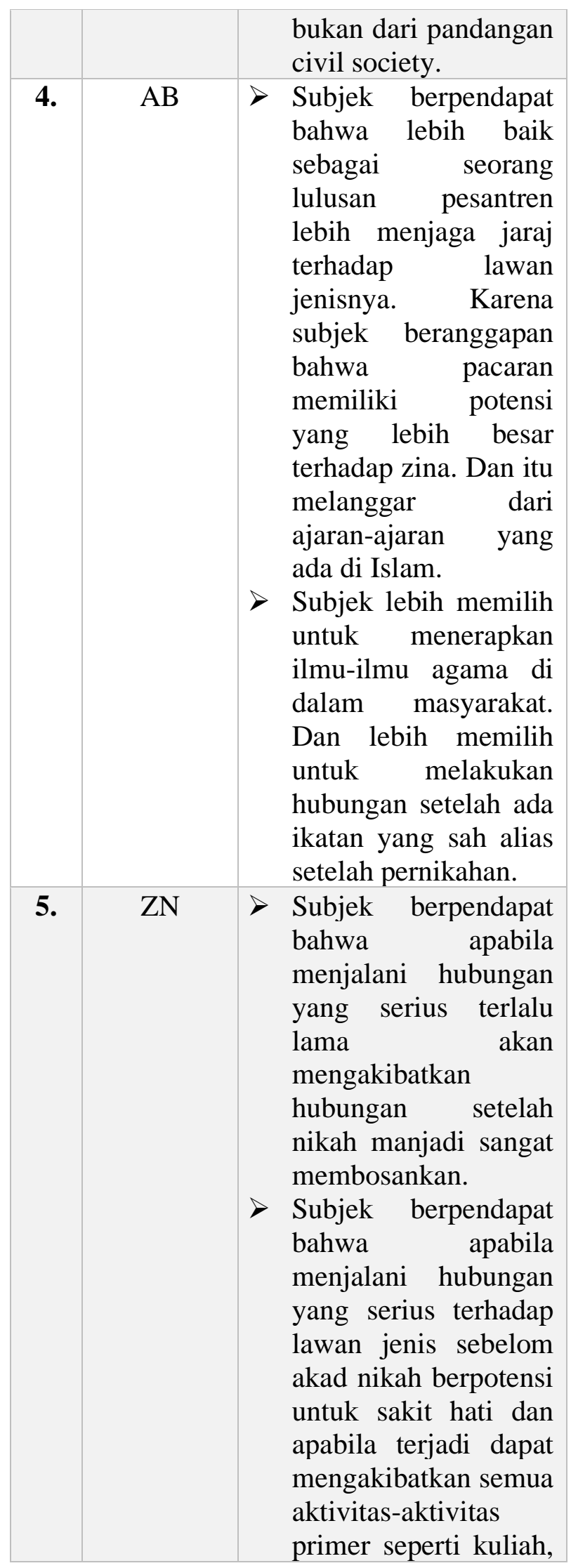




\begin{tabular}{|l|l|}
\hline \multicolumn{2}{|l|}{ membahagiakan } \\
orang tua akan \\
terganggu karena \\
mood di dalam \\
aktivitas sudah turun \\
dan mulai merasakan \\
patah hati. Dan bagi \\
subjek proses move \\
on dari patah hati itu \\
membutuhkan waktu \\
yang sangat lama. \\
\hline
\end{tabular}

c. Struktur peranti mental Ego Universitas berbasis pesantren. Setelah dilakukan proses wawancara kepada subjek-subjek maka di peroleh hasil sebagai beriku dari segi Ego:

\section{NO SUBJEK}

EGO

1. IR
Subjek lebih memilih untuk berkomunikasi secara sewajarnya layaknya sebagai teman di dalam kehidupan. Apabila perasaan terhadap lawan jenis itu datang maka subjek lebih memilih untuk memendam rasa itu di dalam hati. lalu bertekad dan mulai memperlihatkan kepada lawan jenisnya sedikit-demi sedikit

kesuksesannya.

Subjek lebih memilih diakui karena prestasi dan kesuksesan dibanding dengan hanya perasaan cinta semata.

Subjek mengatakan bahwa berhubungan dengan lawan jenis pada masa pra-nikah

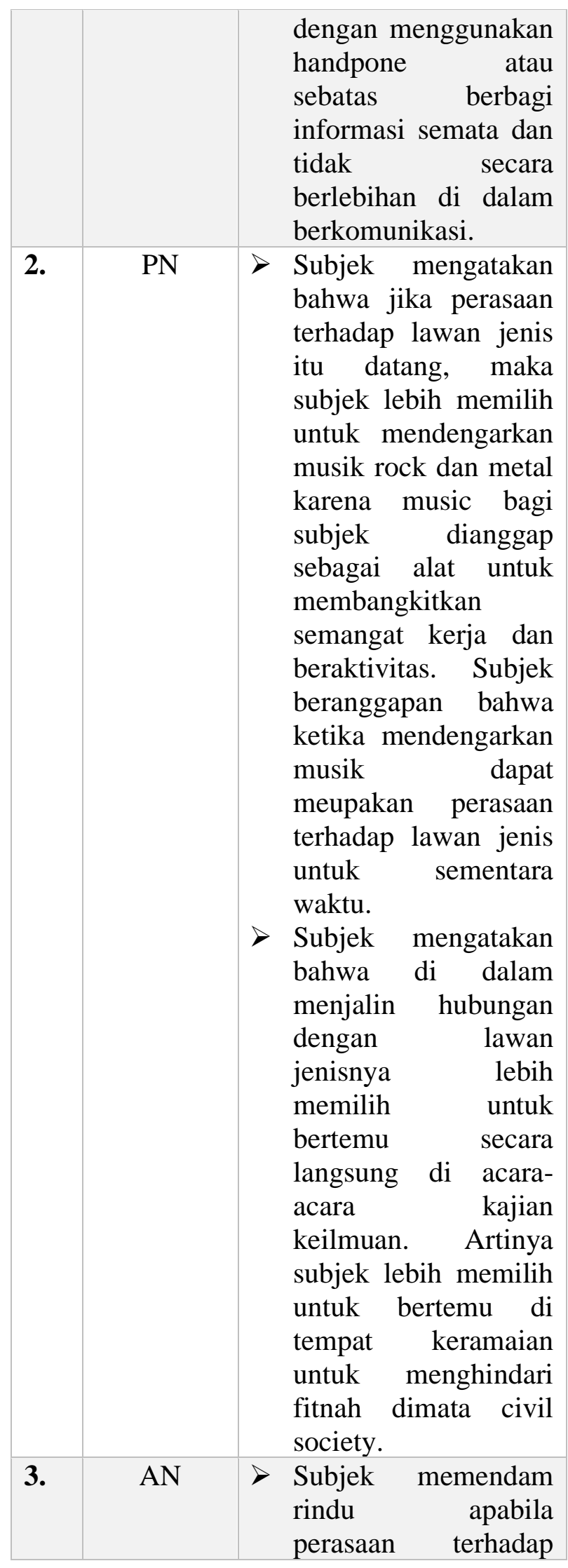




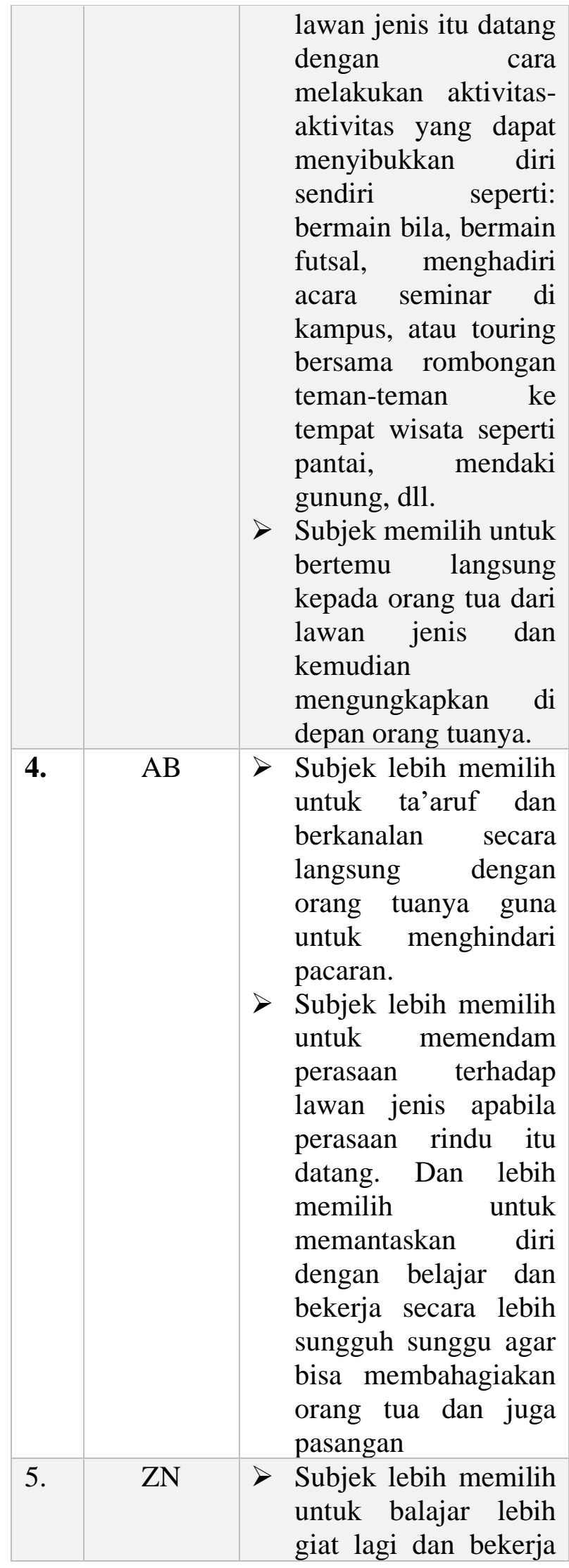

meraih cita-cita baru kemudian menghadap kepada orang tua perempuan untuk sekaligus melamarnya. Subjek tidak setuju dengan istilah pacaran islami. Karena bagi subjek tidak ada istilah pacaran di dalam Islam.

Subjek mengatakan apabila perasaan itu datang maka subjek lebih memilih untuk menyibukkan diri dengan aktivitas kajian keilmuan atau hal-hal yang bermanfaat lainnya 
Berdasarkan hasil dari penelitian diatas dapat kita lihat bahwasannya pada subjek IR, PN, AN, AB, dan $\mathrm{ZN}$ memiliki dorongan ID dalam melakukan hubungan dengan lawan jenis. Kita menelaah pada penelitian ini terdapat semacam hipotesis awal yang mengatakan bahwasannya apakah setiap orang memiliki dorongan dari id untuk melakukan hubungan intim terhadap lawan jenis? Maka hipotesis itu telah terjawab berdasarkan hasil dari penelitian diatas. Dari struktur peranti mental ID berdasarkan penelitian di atas terhadap mahasiswa dan mahasiswi universitas berbasis pesantren mereka semua memiliki perasaan terhadap lawan jenisnya.

Kemudian apabila kita menelaah kepada struktur peranti mental super ego maka dapat kita ambil kesimpulan bahwa pada subjek IR, PN, AN, AB, dan ZN samasama memiliki otoritas moral yang melarang mereka untuk melakukan hubungan intimasi terhadap lawan jenis baik secara langsung maupun tidak langsung. Bagi IR super ego atau yang menjadi batasan di dalam melakukan hubungan intim terhadap lawan jenisnya adalah dirinya sendiri bukan berasal dari orang tuanya. Walaupun pada dasarnya orang tua tetap sebagai pusat otoritas moral namun, orang tua IR menyerahkan kembali ke IR karena mungkin IR telah dianggap dewasa dalam menghadapi masalah hubungan intim ini. Kemudian pada subjek $\mathrm{PN}, \mathrm{AN}, \mathrm{AB}$, dan $\mathrm{ZN}$ super ego mereka lebih mendominasi dalam menjalankan nilainilai agama dan menolak dalam hal pacaran dikarenakan mereka adalah lulusan pondok pesantren dan masih melanjutkan kuliah di universitas pesantren maka mereka secara tidak langsung harus menjaga nama baik mereka di mata civil society.

Kemudian pada struktur peranti mental Ego, rata-rata subjek diatas menggunakan mekanisme pertahanan diri kompensasi yang mana sebuah mekanisme bahwa seseorang lebih memilih mengejar suatu tujuan, dengan usaha yang lebih giat ke dalam usahanya itu untuk mengatasi rasa kekurangan yang sebenarnya. Singkat kata mereka lebih memilih untuk memantaskan diri mereka. Pada tabel di atas subjek IR, $\mathrm{PN}, \mathrm{AN}, \mathrm{AB}$, dan $\mathrm{ZN}$ memiliki perasaan ingin memantaskan diri dengan menganggap diri mereka masih memiliki kekurangan dan termotivasi untuk lebih membuktikan kepada lawan jenisnya dengan kesuksesannya di dalam berkarir.

\section{SIMPULAN}

Struktur peranti mental merupakan tiga sistem penting atau biasa disebut agencies yang berasal dari Freud yang terdiri dari id, ego, dan super ego. Dari hasil penelitian diatas menunjukkan bahwa kelima subjek diatas semuanya memiliki rasa ketertarikan terhadap lawan jenis mereka yang disebut dengan hubungan intimasi. Naluri ini bersifat alamiah dan merupakan id pada struktur peranti mental manusia. Pada semua subjek di atas memiliki hasrat dan dorongan untuk dapat memenuhi keinginannya untuk dekat dengan lawan jenisnya dari segi emosional, seperti rasa rindu dan kasih sayang, cinta, dan ada rasa untuk ingin diperhatikan terhadap lawan jenisnya.

Kenudian pada struktur peranti mental mereka yaitu super ego mereka lebih mendominasi dalam menjalankan nilai-nilai agama dan menolak dalam hal pacaran dikarenakan mereka adalah lulusan pondok pesantren dan masih melanjutkan kuliah di universitas pesantren maka mereka secara tidak langsung harus menjaga nama baik mereka di mata civil society.

Subjek diatas menggunakan mekanisme pertahanan diri kompensasi yang mana sebuah mekanisme bahwa seseorang lebih memilih mengejar suatu tujuan, dengan usaha yang lebih giat ke dalam usahanya itu untuk mengatasi rasa kekurangan yang sebenarnya. Singkat kata mereka lebih memilih untuk memantaskan diri mereka. Sebagian besar subjek diatas memiliki 
perasaan ingin memantaskan diri dengan menganggap diri mereka masih memiliki kekurangan dan termotivasi untuk lebih membuktikan kepada lawan jenisnya dengan kesuksesannya di dalam berkarir.

\section{DAFTAR PUSTAKA}

Alwisol. psikologi Kepribadian. Malang:

UMM Press, 2007.

Boeree. Personality Theories. Terj. Inyiak

Ridwan Muzir. Yogyakarta:

Prismasophie, 2005.

Dariyo, A. Psikologi Perkembangan Dewasa

Muda. Jakarta: Gramedia

Widiasarana Indonesia, 2003.

Hall, C. S. dan Lindzey, G. Dalam A.

Supratiknya (Ed) Teori-teori Holistik

(Organismik-Fenomenologis).

Yogyakarta: kanisius, 1993.

Hurlock. Psikologi Perkembangan. 5 ed. Jakarta: Erlangga, 2004.

Turner, J.S. Lifespan Development. Harcourt
Brace College Publishers, 1995.

Jhon W. Creswell. Research Design:

Pendekatan Metode Kualitatif,

Kuantitatif, dan Campuran. 4 ed.

Yogyakarta: Pustaka Pelajar, 2016.

Monks, F. J., Knoers, A. M. P., \& Haditono, S. R. Psikologi perkembangan (pengantar dalam berbagai bagiannya). Yogyakarta: Gajah Mada University Press, 1996.

Papalia, D.E, Olds, S.W., \& Feldman, R.D. Human Development. 9 ed. New York: McGraw Hill, 2004. ."Human Development," t.t. Septian Eko. "Dinamika Id, Ego, Superego Dalam Konteks Kebutuhan Intimasi (Studi Pada Dewasa Muda Aktivis Dakwah Kampus), 2017.

Yudistriana, Kiki, A. M. Heru Basuki, dan Intaglia Harsanti. Intimasi Pada Pria Dewasa Awal Yang Berpacaran Jarak Jauh Beda Kota. Jurnal Ilmiah Psikologi 3, no. 2, 2011. 